\title{
Penerapan Rapidminer Pada Data Mining Klastering (Kasus: Distribusi Persentase Rumah Tangga Menurut Kabupaten/Kota Dan Bahan Bakar Untuk Memasak)
}

\author{
Ismi Azhami , Rahmi Fauziah ${ }^{2}$ \\ ${ }^{1,2}$ Sekolah Tinggi Ilmu Komputer Tunas Bangsa (STIKOM) Tunas Bangsa \\ Jl. Jendral Sudirman Blok A No/1/2/3 Pematangsiantar, Medan, Indonesia, 21127 \\ ${ }^{1}$ Ismiazhami9@gmail.com, 2fauziahrahmi3108@gmail.com
}

\begin{abstract}
Fuel is any material that can be converted into energy. For example in daily life humans often use energy sources as fuel for cooking including Gas/LPG, Electricity, Kerosene, Charcoal/Briquettes, Wood and others. The purpose of this study is to classify the distribution of the percentage of fuel used in each district/city in Northern Sumatra. This study discusses the analysis of the K-Means method in the case of the distribution of household percentages by district/city and cooking fuel in North Sumatra through the North Sumatra Central Statistics Agency website. The data is processed into 2 clusters namely high level (C1) and low-level clusters (C2). Thus obtained from 34 districts/cities in North Sumatra 23 regions are grouped in high-level clusters $(C 1)$ and 10 regions are grouped in low-level clusters (C2).This needs to be done so that it becomes input in the form of information to the government to find out villages that still have low understanding and have not been fulfilled in a district/city in the Province of North Sumatra.
\end{abstract}

Keywords: Decision Support System, State Civil Apparatus, ELECTRE.

\begin{abstract}
Abstrak
Bahan bakar merupakan suatu materi apapun yang bisa diubah menjadi energi. Seperti contohnya dalam kehidupan sehari-hari manusia sering menggunakan sumber energi sebagai bahan bakar untuk memasak diantaranya Gas/elpiji, Listrik, Minyak Tanah, Arang/Briket Kayu dan lainnya. Tujuan dari penelitian ini untuk mengelompokkan pada kasus distribusi persentase bahan bakar yang di gunakan dari setiap kabupaten/kota di Sumatera Utara. Penelitian ini membahas tentang Analisis Metode K-Means pada kasus distribusi persentase Rumah Tangga Menurut Kabupaten/Kota dan Bahan Bakar untuk Memasak di Sumatera Utara melalui Situs Badan Pusat Statistik Sumut. Data diolah menjadi 2 cluster yaitu cluster tingkat tinggi (C1) Dan cluster tingkat rendah (C2). Sehingga diperoleh dari 34 Kabupaten/Kota di Sumatera Utara 23 daerah dikelompokkan dalam cluster tingkat tinggi (C1), dan 10 daerah dikelompokkan dalam cluster tingkat Rendah (C2). Hal ini perlu dilakukan agar menjadi masukan berupa informasi kepada pemerintah untuk mengetahui desa-desa yang masih memiliki pemahaman rendah dan belum terpenuhi di suatu kabupaten/kota di Provinsi Sumatera Utara
\end{abstract}

Kata kunci: Klastering, K-means, Data Mining, Bahan Bakar.

\section{Pendahuluan}

Bahan bakar merupakan suatu materi apapun yang bisa diubah menjadi energi. Biasanya bahan bakar mengandung energi panas yang dapat dilepaskan dan dimanipulasi. Kebanyakan bahan bakar digunakan manusia melalui proses pembakaran (reaksi redoks) dimana bahan bakar tersebut akan melepaskan panas setelah direaksikan dengan oksigen di udara. Ada beberapa jenis bahan bakar berdasarkan jenis dan wujudnya diantaranya bahan bakar padat yaitu bahan bakar berbentuk padat dan kebanyakan menjadi sumber energi panas. Misalnya kayu dan 
batubara. Kemudian bahan bakar cair adalah bahan bakar yang strukturnya tidak rapat, contohnya minyak tanah,minyak solar dan lain-lain. Selanjutnya bahan bakar gas, terbagi dua jenis, yakni Compressed NaturalGas (CNG) dan Liquid Petroleum Gas(LPG) Seperti contohnya dalam kehidupan sehari-hari manusia sering menggunakan sumber energi sebagai bahan bakar untuk memasak diantaranya Gas/elpiji, Listrik, Minyak Tanah, Arang/Briket, Kayu dan lainnya. Mulai dari bahan bakar yang tradisional hingga yang terbarui masih banyak sebagian masyarakat yang masih menggunakannya. Untuk dapat memahami data dengan mudah, maka baik data kualitatif maupun data kuantitatif harus disajikan dalam bentuk yang ringkas dan jelas. Salah satu cara untuk meringkas data adalah dengan adanya distribusi frekuensi persentase atau pengolompokkan data kedalam beberapa kelompok (kelas) dan kemudian dihitung banyak nya data yang masuk kedalam tiap kelas.

Banyak cabang ilmu komputer yang dapat menyelesaikan masalah secara komplek. Salah satu diantaranya adalah Sistem Pendukung Keputusan [1]-[3], data mining [4]-[7], system pakar [8], [9], jaringan syaraf tiruan [10]-[12], algoritma genetika, dan lain-lain [13]. Cabang ilmu computer tersebut adalah Artificial Intelligence seperti datamining [14]. Datamining adalah proses yang menggunakan teknik statistik, matematika, kecerdasan buatan untuk menemukan hubungan yang jelas serta menyimpulkan yang belum diketahui sebelumnya dengan cara terkini yang dapat dipahami dan berguna bagi pemilik data tersebut [7]. Clustering akan melakukan pengelompokkan data-data ke dalam sejumlah kelompok (cluster) berdasarkan kesamaan karakteristik masing-masing data pada kelompok-kelompok yang ada. Banyak metode yang bisa digunakan untuk melakukan clustering salah satunya adalah metode K-Means. Algoritma K-Means merupakan salah satu teknik pengelompokkan yang bekerja berdasarkan partitioned clustering. Tujuan dari $K$ Means Clustering adalah untuk membagi data kedalam kelompok-kelompok tertentu sehingga menghasilkan pengetahuan baru.

Tujuan dari penelitian ini untuk mengelompokkan distribusi persentase bahan bakar yang di gunakan dari setiap kabupaten/kota di Sumatera Utara. Hal ini perlu dilakukan agar menjadi masukan berupa informasi kepada pemerintah untuk mengetahui desa-desa yang masih memiliki pemahaman rendah dan belum terpenuhi di suatu kabupaten/kota. Berdasarkan Penelitian terdahulu yang dilakukan oleh Mahasiswa Sekolah Tinggi Manajemen Informatika dan Komputer Nusa Mandiri (STMIK Nusa Mandiri) yang berjudul "Klasifikasi Data Mining pada Rumah Tangga Menurut Provinsi dan Status Kepemilikan Rumah Kontrakan/ Sewa Menggunakan K-Means Clustering Method" Penelitian ini menjadi salah satu acuan penulis dalam melakukan penelitian sehingga penulis dapat memperkaya teori yang di gunakan dalam mengkaji penelitian yang dilakukan. Dari penelitian terdahulu, penulis tidak menemukan penelitian dengan judul yang sama seperti judul penelitian penulis. Namun penulis mengangkat beberapa penelitian sebagai referensi dalam memperkaya bahan kajian pada penelitian penulis. Berdasarkan penelitian diatas, maka peneliti mengangkat judul "Penerapan Rapidminer Pada Data Mining Klastering (Kasus: Distribusi Persentase Rumah Tangga Menurut Kabupaten/Kota dan Bahan Bakar UntukMemasak)". Diharapkan nantinya hasil penelitian yang didapatkan adalah daerah Kabupaten/Kota mana yang paling rendah ini dapat menjadi masukan bagi pemerintah untuk memberikan pemahaman kepada masyarakat/desa agar meratanya kesejahteraan rakyat.

\section{Metodologi Penelitian}

Dalam metodologi penelitian ini metode yang digunakan adalah metode data mining mining sebagai berikut. (a) Tahap pengumpulan data, (b) Tahap pengolahan 
data, (c) Tahap Clustering dan (d) Tahap Analisis. Tahapan dalam metode tersebut dijelaskan sebagai berikut:

\subsection{Tahapan Pengumpulan Data}

Dalam penelitian ini, Sumber data penelitian diperoleh dari Badan Pusat Statistik Sumatera Utara (BPS Sumut) dimana data tersebut adalah data distribusi presentase rumah tangga menurut kabupaten/kota dan bahan bakar untuk memasak di Sumatera Utara melalui situs https://www.sumut.bps.go.id. Data dibagi menjadi 2 cluster yaitu cluster tingkat tinggi dan cluster tingkat rendah.

\subsection{Tahapan Pengolaha Data}

Data yang telah diperoleh akan diolah terlebih dahulu untuk diclustering dan diolah dengan software Rapidminer berdasarkan cluster yang sudah ditentukan sebelumnya.

\subsection{Tahapan Klastering}

Clustering atau klasterisasi adalah metode pengelompokan data [7], [15]. Clustering adalah sebuah proses untuk mengelompokkan data ke dalam beberapa cluster atau kelompok sehingga data dalam satu cluster memiliki tingkat kemiripan yang maksimum dan data antar cluster memiliki kemiripan yang minimum [16]. Dalam menentukan cluster berdasarkan data yang telah tersedia, dibutuhkan sebuah flowchart untuk memudahkan dalam menentukan alur perhitungan sebagai alur untuk menemukan hasil dari penerapan cluster terhadap data yang akan diproses. Berikut adalah flowchart dalam menentukan cluster dengan K-Means [5].

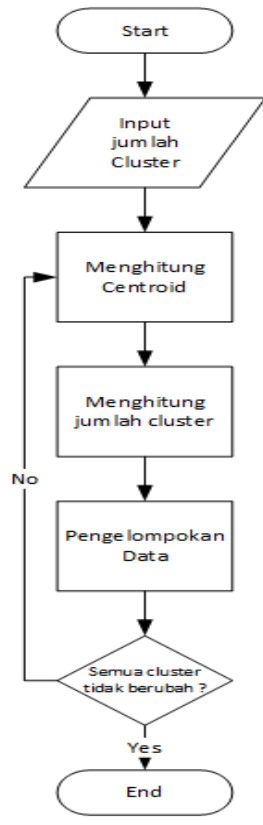

\section{Gambar 1. Flowchart K-Means}

\subsection{Tahapan Pengolaha Data}

Pada tahapan ini dilakukan analisis data ekspor buah buahan menurut negara tujuan aplikasi tool. Rapid Minner. RapidMiner adalah sebuah lingkungan machine learning data mining, text mining dan predictive analytic. Dalam menganalisa pengelompokkan fasilitas prguruan tinggi. Data yang telah diperoleh, kemudian diolah menggunakan perhitungan bobot dari tiap indeks. Pada tahapan sebelumnya, telah ditentukan akan dicluster ke dalam 2 cluster diantaranya cluster rendah dan cluster tinggi, yang hasilnya akan dianilisis. 


\section{Hasil Pembahasan}

Dalam penelitian ini, sumber data diambil dari Badan Pusat Statistik https://www.sumut.bps.go.id. Dimana data tersebut merupakan data berdasarkan Kabupaten/Kota tahun 2018.

Tabel 1. Distribusi Persentase Rumah Tangga Menurut Kabupaten/Kota dan Bahan Bakar Utama Untuk Memasak di Provinsi Sumatera Utara, 2018

\begin{tabular}{|c|c|c|c|c|c|c|}
\hline Kabupaten/ Kota & Listrik & Gas/ Elpiji & $\begin{array}{l}\text { Minyak } \\
\text { Tanah }\end{array}$ & $\begin{array}{l}\text { Arang/ } \\
\text { Briket }\end{array}$ & Kayu & Lainnya \\
\hline $\mathrm{N}$ i a $\mathrm{s}$ & 0 & 0.48 & 9.53 & 0.48 & 89.5 & 0.01 \\
\hline Mandailing Natal & 0.07 & 38.84 & 5.73 & 0.29 & 55.06 & 0 \\
\hline Tapanuli Selatan & 0 & 33.9 & 4.64 & 0.4 & 61.06 & 0 \\
\hline Tapanuli Tengah & 0.21 & 50.14 & 3.03 & 0.63 & 45.99 & 0 \\
\hline Tapanuli Utara & 0 & 71.98 & 0.52 & 1.08 & 26.31 & 0.12 \\
\hline Toba Samosir & 0.13 & 81.02 & 1.38 & 0.76 & 16.71 & 0 \\
\hline Labuhanbatu & 0 & 90.89 & 1.68 & 0.92 & 6.51 & 0 \\
\hline As ahan & 0.42 & 95.53 & 1.17 & 1.15 & 1.72 & 0 \\
\hline Simalungun & 0.34 & 92.05 & 0.25 & 0.38 & 6.75 & 0.23 \\
\hline D a i r i & 1.12 & 81.21 & 0.49 & 0.54 & 16.64 & 0 \\
\hline $\mathrm{K}$ a $\mathrm{r}$ o & 0.93 & 93.76 & 0.14 & 0.55 & 4.62 & 0 \\
\hline Deli Serdang & 0.6 & 93.61 & 2.92 & 1.02 & 1.85 & 0 \\
\hline Langkat & 0.06 & 92.56 & 1.95 & 0.38 & 5.06 & 0 \\
\hline Nias Selatan & 1.7 & 4.07 & 11.16 & 0 & 82.88 & 0.19 \\
\hline Humbang Hasundutan & 0 & 69.89 & 0.22 & 0.47 & 29.42 & 0 \\
\hline Pakpak Bharat & 0 & 58 & 0 & 1.26 & 40.74 & 0 \\
\hline Samosir & 0 & 71.59 & 0.21 & 0.24 & 27.95 & 0 \\
\hline Serdang Bedagai & 0.23 & 92.63 & 1.36 & 0.78 & 4.99 & 0 \\
\hline Batu Bara & 0.11 & 94.67 & 0.85 & 1.89 & 2.48 & 0 \\
\hline PadangLawas Utara & 0 & 52.42 & 3.3 & 0.57 & 43.43 & 0.28 \\
\hline Padang Lawas & 1.29 & 46.4 & 4.17 & 1.39 & 46.61 & 0.14 \\
\hline Labuhanbatu Selatan & 0.04 & 85.51 & 2.56 & 0.39 & 11.51 & 0 \\
\hline Labuhanbatu Utara & 0 & 89.81 & 0.29 & 0.46 & 9.45 & 0 \\
\hline Nias Utara & 0.99 & 1.27 & 12.79 & 0.17 & 84.79 & 0 \\
\hline Nias Barat & 0 & 1.01 & 8.88 & 0.02 & 90.09 & 0 \\
\hline Sibolg a & 0.55 & 82.01 & 12.54 & 2.83 & 1.91 & 0.16 \\
\hline Tanjungbalai & 0 & 95.76 & 1.74 & 1.01 & 1.48 & 0 \\
\hline Pematangsiantar & 0.47 & 95.67 & 1.61 & 1.61 & 0.29 & 0.35 \\
\hline Tebing Tinggi & 0 & 93.76 & 2.84 & 0.97 & 2.18 & 0.25 \\
\hline Medan & 2.64 & 86.8 & 8.09 & 1.88 & 0.59 & 0 \\
\hline $\mathrm{B}$ in j a i & 0.09 & 90.6 & 6.45 & 2.3 & 0.55 & 0 \\
\hline Padangsidimpuan & 0.17 & 71.36 & 14.22 & 0.51 & 13.74 & 0 \\
\hline Gunungsitoli & 0.15 & 10.47 & 44.45 & 0.41 & 44.53 & 0 \\
\hline
\end{tabular}

\subsection{Penerapan Aplikasi Rapidminer}

Hasil pengelompokan data distribusi persentase bahan bakar berdasarkan kabupaten/kota dengan Rapid Miner:

a) Data view: merupakan sheet di Result Perspective untuk menampilkan data yang telah diolah secara keseluruhan lengkap dengan klasternya dari example set (read excel). Data view dapat lihat pada gambar berikut: 


\begin{tabular}{|c|c|c|c|c|c|c|c|c|}
\hline & ar & (5) & 2 & 800 & $\square$ & \multicolumn{3}{|l|}{ 可 i } \\
\hline \multicolumn{9}{|c|}{ 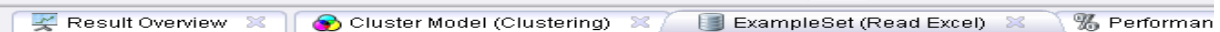 } \\
\hline \multicolumn{9}{|c|}{ (-) Data View $\bigcirc$ meta Data View $\bigcirc$ plot View $\bigcirc$ Advanced charts $\bigcirc$ Annotations } \\
\hline \multicolumn{9}{|c|}{ ExampleSet ( 33 examples, 2 special attributes, 6 regular attributes) } \\
\hline \multirow{2}{*}{\multicolumn{2}{|c|}{ Row No. id }} & cluster & Listrik & Gas/ Elpiji & Minyak & Arang/Briket & Kayu & Lainnya \\
\hline & 1 & cluster_1 & o & 0.480 & 9.530 & 0.480 & 89.500 & 0.010 \\
\hline 2 & 2 & cluster_1 & 0.070 & 38.840 & 5.730 & 0.290 & 55.060 & 0 \\
\hline 3 & 3 & cluster_1 & 0 & 33.900 & 4.640 & 0.400 & 61.060 & 0 \\
\hline 4 & 4 & cluster_1 & 0.210 & 50.140 & 3.030 & 0.630 & 45.990 & 0 \\
\hline 5 & 5 & cluster_o & 0 & 71.980 & 0.520 & 1.080 & 26.310 & 0.120 \\
\hline 6 & 6 & cluster_o & 0.130 & 81.020 & 1.380 & 0.760 & 16.710 & 0 \\
\hline 7 & 7 & cluster_o & 0 & 90.890 & 1.680 & 0.920 & 6.510 & 0 \\
\hline 8 & 8 & cluster_o & 0.420 & 95.530 & 1.170 & 1.150 & 1.720 & 0 \\
\hline 9 & 9 & cluster_o & 0.340 & 92.050 & 0.250 & 0.380 & 6.750 & 0.230 \\
\hline 10 & 10 & cluster_o & 1.120 & 81.210 & 0.490 & 0.540 & 16.640 & 0 \\
\hline 11 & 11 & cluster_o & 0.930 & 93.760 & 0.140 & 0.550 & 4.620 & 0 \\
\hline 12 & 12 & cluster_o & 0.600 & 93.610 & 2.920 & 1.020 & 1.850 & 0 \\
\hline 13 & 13 & cluster_o & 0.060 & 92.560 & 1.950 & 0.380 & 5.060 & 0 \\
\hline 14 & 14 & cluster_1 & 1.700 & 4.070 & 11.160 & 0 & 82.880 & 0.190 \\
\hline 15 & 15 & cluster_o & 0 & 69.890 & 0.220 & 0.470 & 29.420 & 0 \\
\hline 16 & 16 & cluster_o & 0 & 58 & 0 & 1.260 & 40.740 & 0 \\
\hline 17 & 17 & cluster_o & 0 & 71.590 & 0.210 & 0.240 & 27.950 & 0 \\
\hline 18 & 18 & cluster_o & 0.230 & 92.630 & 1.360 & 0.780 & 4.990 & 0 \\
\hline 19 & 19 & cluster_o & 0.110 & 94.670 & 0.850 & 1.890 & 2.480 & 0 \\
\hline
\end{tabular}

Gambar 1. Data view data distribusi persentase bahan bakar berdasarkan kabupaten/kota

b) Flot view : merupakan sheet di Result Perspective untuk menampilkan data yang telah diolah secara keseluruhan lengkap dengan klasternya dari example set (read excel) dalam bentuk diagram Scatter. Tampilannya dapat dilihat pada gambar berikut:

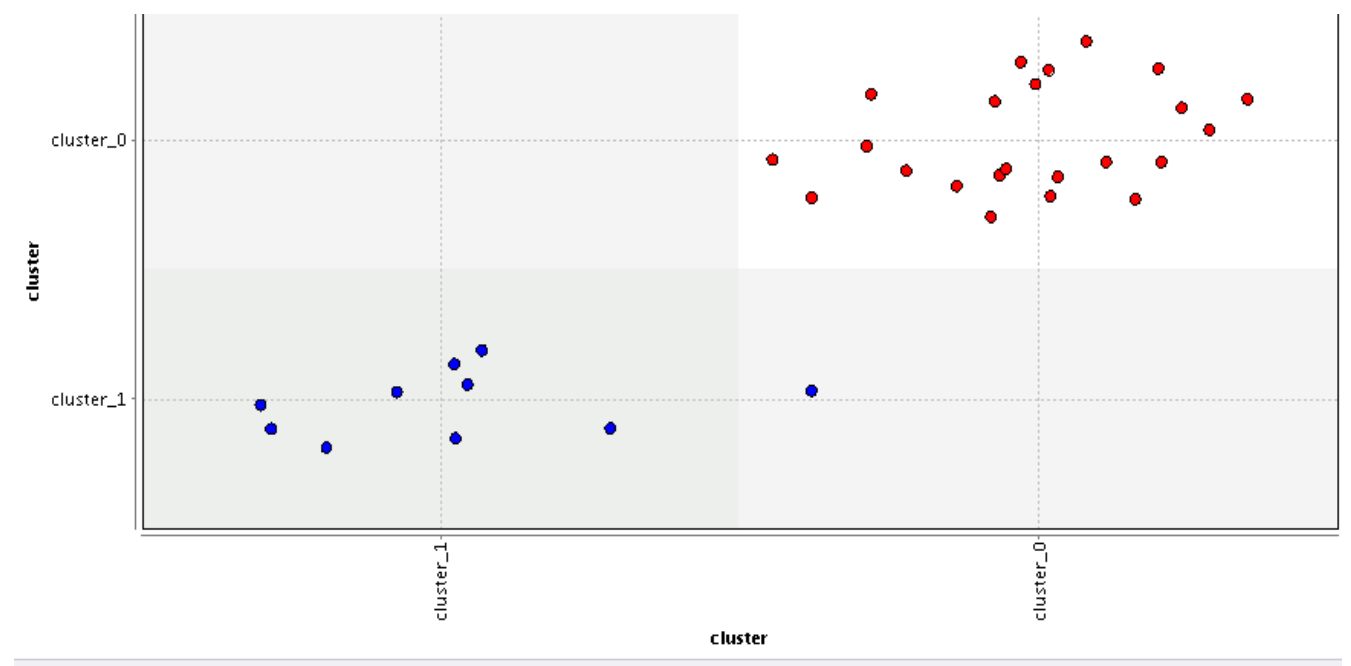

Gambar 2. Flot view data distribusi persentase bahan bakar berdasarkan kabupaten/kota

c) Text view : merupakan sheet untuk menampilkan database yang telah diolah secara keseluruhan lengkap dengan clusternya. Tampilan dari cluster model (clustering) dapat lihat pada gambar berikut:

\section{Cluster Model \\ Cluster 0: 23 items \\ Cluster 1: 10 items \\ Total number of items: 33}

Gambar 3. Flot view hasil cluster dengan RapidMiner 
d) Folder view : merupakan sheet untuk menampilkan database yang telah diolah secara keseluruhan lengkap dengan clusternya. Tampilan folder view dapat dilihat pada gambar berikut:

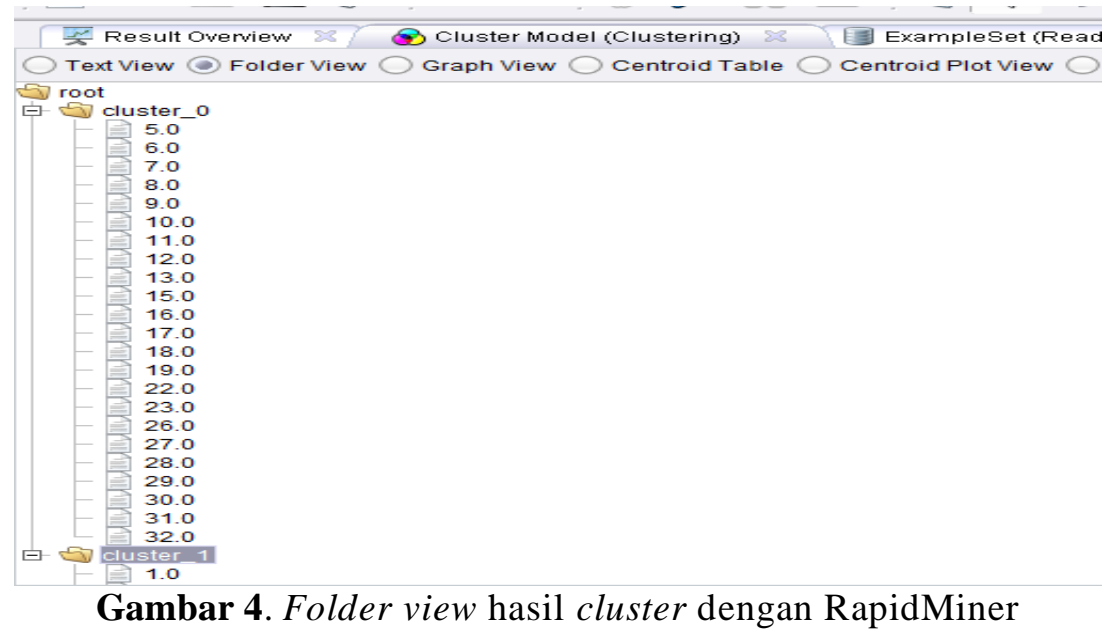

\section{Kesimpulan}

Untuk melakukan penilaian terhadap hasil distribusi persentase rumah tangga menurut kabupaten/kota dan bahan bakar untuk memasak dapat menerapkan metode Clustering $k$ Means. Data diolah untuk memperoleh nilai centroid 2 cluster yaitu cluster tingkat tinggi (C1) dan cluster tingkat rendah (C2). Dimana hasil penelitian menyimpulkan dari 34 daerah di Sumatera Utara dan 2 cluster yang ada diperoleh 23 daerah dengan cluster tingkat tinggi (C1), yaitu Tapanuli Utara, Toba Samosir, Labuhanbatu, Asahan, Simalungun, Dairi, Karo, Deli Serdang, Langkat, Nias Selatan, Humbang Hasundutan, Pakpak Bharat, Samosir, Serdang Bedagai, Batubara, Labuhanbatu Selatan, Labuhanbatu Utara, Sibolga, Tanjungbalai, Pematangsiantar, Tebing Tinggi, Medan, Binjai, Padangsidimpuan dan 10 daerah lainnya dengan cluster rendah $(C 2)$.

\section{Daftar Pustaka}

[1] S. Sundari, Karmila, M. N. Fadli, D. Hartama, A. P. Windarto, and A. Wanto, "Decision Support System on Selection of Lecturer Research Grant Proposals using Preferences Selection Index," J. Phys. Conf. Ser., vol. 1255, no. 1, pp. 1-8, 2019, doi: 10.1088/1742-6596/1255/1/012006.

[2] T. Imandasari, M. G. Sadewo, A. P. Windarto, A. Wanto, H. O. Lingga Wijaya, and R. Kurniawan, "Analysis of the Selection Factor of Online Transportation in the VIKOR Method in Pematangsiantar City," J. Phys. Conf. Ser., vol. 1255, no. 012008, pp. 1-7, 2019, doi: 10.1088/1742-6596/1255/1/012008.

[3] K. Fatmawati et al., "Analysis of Promothee II Method in the Selection of the Best Formula for Infants under Three Years," J. Phys. Conf. Ser., vol. 1255, no. 1, 2019, doi: 10.1088/1742-6596/1255/1/012009.

[4] M. Widyastuti, A. G. Fepdiani Simanjuntak, D. Hartama, A. P. Windarto, and A. Wanto, "Classification Model C.45 on Determining the Quality of Custumer Service in Bank BTN Pematangsiantar Branch,” J. Phys. Conf. Ser., vol. 1255, no. 012002, pp. 1-6, 2019, doi: 10.1088/1742-6596/1255/1/012002.

[5] A. P. Windarto et al., "Analysis of the K-Means Algorithm on Clean Water Customers Based on the Province," J. Phys. Conf. Ser., vol. 1255, no. 1, 2019, doi: 10.1088/1742-6596/1255/1/012001.

[6] W. Katrina, H. J. Damanik, F. Parhusip, D. Hartama, A. P. Windarto, and A. Wanto, "C.45 Classification Rules Model for Determining Students Level of Understanding of the Subject," J. Phys. Conf. Ser., vol. 1255, no. 012005, pp. 1-7, 
2019, doi: 10.1088/1742-6596/1255/1/012005

[7] M. G. Sadewo, A. Eriza, A. P. Windarto, and D. Hartama, "Algoritma K-Means Dalam Mengelompokkan Desa / Kelurahan Menurut Keberadaan Keluarga Pengguna Listrik dan Sumber Penerangan Jalan Utama Berdasarkan Provinsi," Semin. Nas. Teknol. Komput. Sains SAINTEKS 2019, pp. 754-761, 2019.

[8] C. H. Mubarok, "Sistem Pakar Diagnosa Penyakit Anak Yang Disebabkan Virus Berbasis Web," pp. 2-6.

[9] N. Jarti and R. Trisno, "Sistem Pakar Diagnosa Penyakit Alergi Pada Anak Berbasis Web Dengan Metode Forward Chaining," J. Edik Inform., vol. 3, no. 2, pp. 197-205, 2017.

[10] A. P. Windarto, M. R. Lubis, and Solikhun, "Model Arsitektur Neural Network Dengan Backpropogation Pada Prediksi Total Laba Rugi Komprehensif Bank Umum Konvensional," Kumpul. J. Ilmu Komput., vol. 05, no. 02, pp. 147-158, 2018.

[11] Solikhun, A. P. Windarto, Handrizal, and M.Fauzan, "Jaringan Saraf Tiruan Dalam Memprediksi Sukuk Negara Ritel Berdasarkan Kelompok Profesi Dengan Backpropogation Dalam Mendorong Laju Pertumbuhan Ekonomi," Kumpul. J. Ilmu Komput., vol. 04, no. 02, pp. 184-197, 2017.

[12] A. P. Windarto, "Implementasi Jst Dalam Menentukan Kelayakan Nasabah Pinjaman Kur Pada Bank Mandiri Mikro Serbelawan Dengan Metode Backpropogation," J-SAKTI (Jurnal Sains Komput. dan Inform., vol. 1, no. 1, pp. 12-23, 2017.

[13] R. Rahim et al., "Enhanced pixel value differencing with cryptography algorithm," in MATEC Web of Conferences 197, 2018, vol. 03011, pp. 1-5.

[14] D. Hartama, A. Perdana Windarto, and A. Wanto, "The Application of Data Mining in Determining Patterns of Interest of High School Graduates," J. Phys. Conf. Ser., vol. 1339, no. 1, 2019, doi: 10.1088/1742-6596/1339/1/012042.

[15] P. Alkhairi and A. P. Windarto, "Penerapan K-Means Cluster Pada Daerah Potensi Pertanian Karet Produktif di Sumatera Utara," Semin. Nas. Teknol. Komput. Sains, pp. 762-767, 2019.

[16] R. W. Sari, A. Wanto, and A. P. Windarto, "Implementasi Rapidminer Dengan Metode K-Means (Study Kasus: Imunisasi Campak Pada Balita Berdasarkan Provinsi)," KOMIK (Konferensi Nas. Teknol. Inf. dan Komputer), vol. 2, no. 1, pp. 224-230, 2018, doi: 10.30865/komik.v2i1.930. 